\title{
ASSESSMENT OF OLD BUILDINGS IN LASEM CITY BASED ON TIERED QUANTITATIVE ANALYSIS METHOD WITH WeIghting FACTORS
}

\author{
Andi Putranto *, Dwi Pradnyawan \\ Universitas Gadjah Mada \\ Departemen Arkeologi, FIB UGM, Bulaksumur, Yogyakarta 55281, Indonesia \\ *andi.fib@ugm.ac.id
}

Received: 07/09/2018; revisions: 21/09 - 14/12/2018; accepted: 22/12/2018

Published online: $31 / 12 / 2018$

\begin{abstract}
Old buildings in Lasem City are a historical heritage from the colonial period. Based on Law Number 11 of 2010 on Cultural Heritage, these buildings can be categorized as Cultural Buildings if they have gone through the process of registration and assessment and finally designated by the government according to their rank. The assessment of old buildings in Lasem City which are considered to have the characteristics of a cultural heritage building must be performed first as a basis for making recommendations for the government in making the designation as cultural heritage buildings following applicable laws and regulations. The assessment of cultural heritage, especially from the types of building objects has been performed mainly in the context of preparing recommendations for designation, but the assessment mechanism applied is unknown. Therefore, this research introduces the mechanism of assessment model that applies tiered quantitative analysis methods with weighting factors. This method is commonly used in various research in the exact sciences, especially in evaluating land. This method is an adaptation of the spatial analysis method based on the algorithm. The results of the assessment with this model will be able to formulate the expected formula as well as can produce the final value for building object in order to obtain a class in relation to recommendations for designation as cultural heritage buildings. In this research, four recommendation classes were proposed, namely building which is not suitable or not recommended, recommended building with sufficient level, recommended building with strong level, and recommended building with urgent level. These four levels are closely related to the priority scale in a series of designation as cultural heritage buildings. The results of this research are expected to obtain a quantitative value and scientifically measured in the procedure for assessing buildings for designation as cultural heritage buildings.
\end{abstract}

Keywords: old building; China; preservation; cultural heritage; assessment

\section{INTRODUCTION}

Cultural heritage preservation of old buildings from the Colonial period is more dominant than other types of cultural heritage buildings. So far, the determination of cultural heritage building parameters has been performed by using several variables as the basis for its preparation. The main problem is not the variables used as the basis for the preparation of these parameters, but rather the process of parameters assessment which has an impact on the way of further analysis to produce ratings related to the extent to which a building is feasible and meets the requirements of cultural heritage buildings. So far, the parameters assessment of cultural heritage building is more qualitative, which tends to be difficult to process to produce absolute values. Quantitative assessment models have not been widely used, especially in archeology. This assessment model is more widely used in the fields of sciences such as geography, forestry, which are related to land evaluation (Hardjowigeno \& Widiatmaka, 2007). By using a quantitative assessment model, each variable that composes these parameters can be processed mathematically and uses simple statistics but produces a value that is more rational, logical and comprehensive.

Assessment of buildings that have the potential for designation as cultural heritage remains based on the principles of modern preservation. The main elements in these principles include Integrity and Authenticity, or in other words is an entity, both between building components and the surrounding environment in the course of time history and the principle of authenticity (Grementieri, 2003). Several ideas or parameters that can be proposed as new paradigms are: conditions related to political, economic, socio-cultural situations; assessment 
scale and assessment objectives; realm of assessment; starting point of assessment; regional conditions; foreign influence to the building; adaptation, utilization; linkage with the original country of origin (Roosmalen, 2003).

This research focused on one of the cities on the north coast of Java, namely Lasem city which is a sub-district in Rembang Regency. This city was chosen because it has quite a few unique cultural heritage, namely Chinese architectural buildings that have not yet been designated as cultural heritage buildings following the mandate of Law No. 1 of 2010 (Undang-Undang RI, 2010) on Cultural Heritage.

The purpose of this research is to answer a number of questions, including:

1. What is the assessment result of old buildings in Lasem City based on quantitative analysis method?

2. To what extent can the model rank the buildings according to the value of the recommendations obtained?

The purpose of this research is to obtain quantitative assessment result that is expected to be closer to reality (realistic) and objective that occurs as well as develops in conservation site, in the context of cultural heritage building values.

\section{MeTHODS}

This research is quantitative; the data obtained were analyzed using a tiered quantitative analysis method with weighting factors. Furthermore, the final value was obtained based on the index arranged, so that it can be designated as a cultural heritage building. The instruments used as the basis for the preparation of the assessment variables in this study were the instruments proposed and applied by Harold Kalman in 1980 in the United States that was used to assess historical buildings (Kalman, 1980; URHC Team, 2013). In this research, the instruments were modified or adapted to the research objectives and the characters of old buildings in Lasem particularly.

Assessment instruments that were compiled based on the valuation model were modified or adjusted, considering that the models were used in other countries, as well as mathematical assessment models that were deemed more likely to common sense or subjective according to the appraiser. Therefore, modifications were attempted by applying mathematical models for calculating final values commonly used in the field of spatial research for assessment of land evaluation which is commonly known as tiered quantitative analysis with weighting factors. The assessment parameters in this research were:

1. Architecture with the sub-parameters assessed including style, construction, period/age, architect, design, and interior.
2. Historical with the sub-parameters assessed including linkage with figures, historical event, and historical context.

3. The environment with the sub-parameters assessed including sustainability, layout, and symbol/landmark.

4. Utilization with the sub-parameters assessed including suitability, adaptation, public, utility, and financing.

5. Integrity and Authenticity with the sub-parameters assessed including site (position), alteration (change), and structural condition.

Each of the sub-parameters above will be given a number value from 1-4. The number represented the difference in value from the lowest to the highest. Following the tiered quantitative analysis method with weighting factors, each of the parameters above was given a weight value. Weight here was different from the score (Putranto, Sutikno, \& Suharyadi, 2015; Suharyadi $\&$ Aktiva, 2005). The weight given in this study were 1 and 2. The consideration of weight determination was performed subjectively by researchers based on the theoretical approach. Details of the parameters can be seen in Table 1:

Table 1. Assessment Parameters

\begin{tabular}{clc}
\hline No & Assessment Parameters & Weight value \\
\hline 1 & Architecture & 2 \\
\hline 2 & History & 2 \\
\hline 3 & Environment & 1 \\
\hline 4 & Utilization & 1 \\
\hline 5 & Integrity and Authenticity & 2 \\
\hline
\end{tabular}

The overall results of the following assessment with the predetermined weight values were calculated with the following mathematical/algorithmic model:

$$
\begin{aligned}
& \mathrm{HKB}=(\mathrm{HVA} * \mathrm{~PB})+(\mathrm{HVB} * \mathrm{~PB})+(\mathrm{HVC} * \mathrm{~PB})+ \\
& \quad(\mathrm{HVD} * \mathrm{~PB})+(\mathrm{HVE} * \mathrm{~PB}) \\
& \mathrm{HKB}= \text { Total Value } \\
& \mathrm{HVA}=\text { Architectural Value } \\
& \mathrm{HVB}= \text { Historical Value } \\
& \mathrm{HVC}= \text { Environmental Value } \\
& \mathrm{HVD}= \text { Utilization Value } \\
& \mathrm{HVE}=\text { Integrity } \& \text { Authenticity Value } \\
& \mathrm{PB}=\text { Weight }
\end{aligned}
$$

Furthermore, the total value of each building assessed was grouped according to the interval class from the lowest to the highest total value range and divided into four interval classes. The lowest class was 32, and the highest class was 128. Then the class interval was divided into four classes, namely, Not Recommended; Recommended for designation as a Sufficient level; recommended for designation in Strong level, and recommended for designation at Urgent level. 


\section{RESULT AND DISCUSSION}

\section{History}

Apart from its unique history from the side of Chinese culture, Lasem has a long history. Although there are several folktales about the old history in the first millennium of $\mathrm{CE}$, an apparent history emerged around the $14^{\text {th }}$ century, precisely where Lasem was mentioned as one of the core regions of the Majapahit Kingdom. In a few inscriptions and some ancient manuscripts compiled in the Majapahit Period, it is mentioned that Lasem was included in the core regions of the Majapahit Kingdom which was controlled by a Bhatara known as Bhre Lasem (Djafar, 2009). Bhre Lasem was known as one of the close relatives of Majapahit's king. This indicates that the Lasem region was an important area in Java in the $14^{\text {th }}$ century (Atabik, 2016: 38). After the fall of Majapahit Kingdom and the beginning of Islamic Empire domination, attention was shifted to the regions of Pati, Juwana, Demak, Kudus, and Semarang which were more developed and became commercial, economic, and power centers (de Graaf \& Pigeaud, 2003). Along with that, the history of Lasem began to fade. It is associated with the arrival of Admiral Cheng Ho's Fleet around the $15^{\text {th }}$ century (Armani \& Arbi, 2014: 2).

The name Lasem reappeared in the $18^{\text {th }}$ century when Lasem was said to be one of the Chinese escapees who rebelled against the VOC in the 1740s in Batavia, known as Geger Pacinan (Pacinan Commotion) in the Javanese tradition (Handinoto, 2015). According to the story, the rebellion from Lasem affected the conditions in Mataram and caused the fall of Mataram palace in Kartasura and was followed by the transfer of Kedaton to Surakarta. In the $19^{\text {th }}$ century, Lasem also became one of the centers for opium smuggling, many of the Chinese people involved in the opium trade. In fact, some Chinese houses have tunnels to smuggle the opium. After that, Lasem's role was further diminished by the transfer of the capital Lasem as an area that encompassed several surrounding areas to Rembang City until now (Gunawan et al., 2008: 58).

\section{The Morphology of Lasem City}

The city of Lasem as part of a traditional city in Java has elements like other traditional cities. Lasem has an urban morphology or component known as catur tunggal that is the square, market, worship place, and place of the ruler. The traditional catur tunggal city concept always has the above components centered in one place (four parts in one place or catur tunggal) This concept is believed to be a development of the city formation during Majapahit period (Septirina et al., 2016: 261). From the city sketches made by Pratiwo (2010), the development of Lasem city appeared from around the $15^{\text {th }}$ century until the 1990s development can be seen in Figure 2 to Figure 8.

The development of urban spatial planning from time to time affects changes in the urban morphology, both new emerging, and missing elements (Esri Press Team, February 28, 2018). Significant element changes are the loss of catur tunggal elements, that is the ruler's place and the square, and what remains is the worship place element, in this case, is the mosque and the existence of the market. Morphological elements that developed significantly were the emergence of settlements which were increasingly dense over time, in this case, the ethnic Chinese settlements in Lasem.

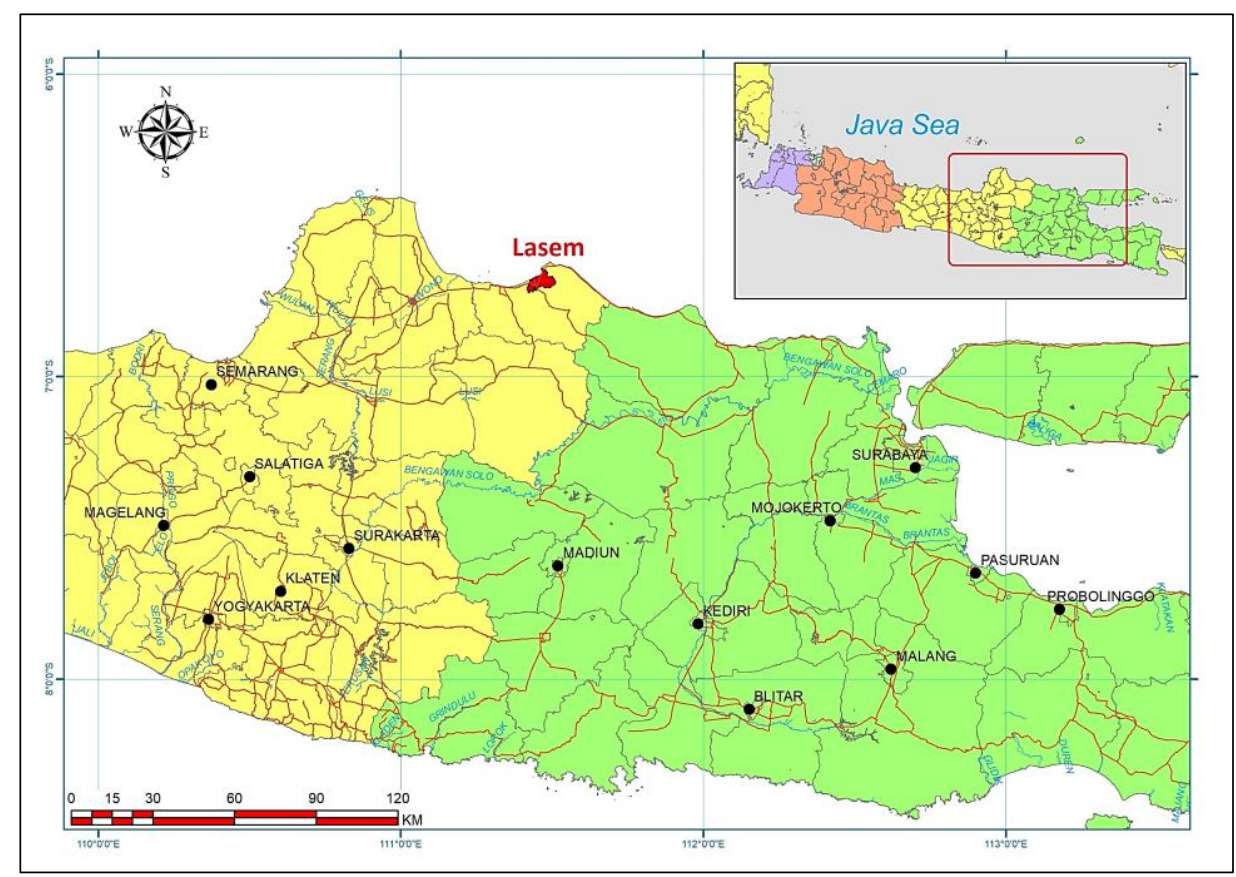

Figure 1. The location of Lasem Subdistrict

(Source: Basemap data from Badan Informasi Geospasial (BIG), modified by the authors, 2018) 


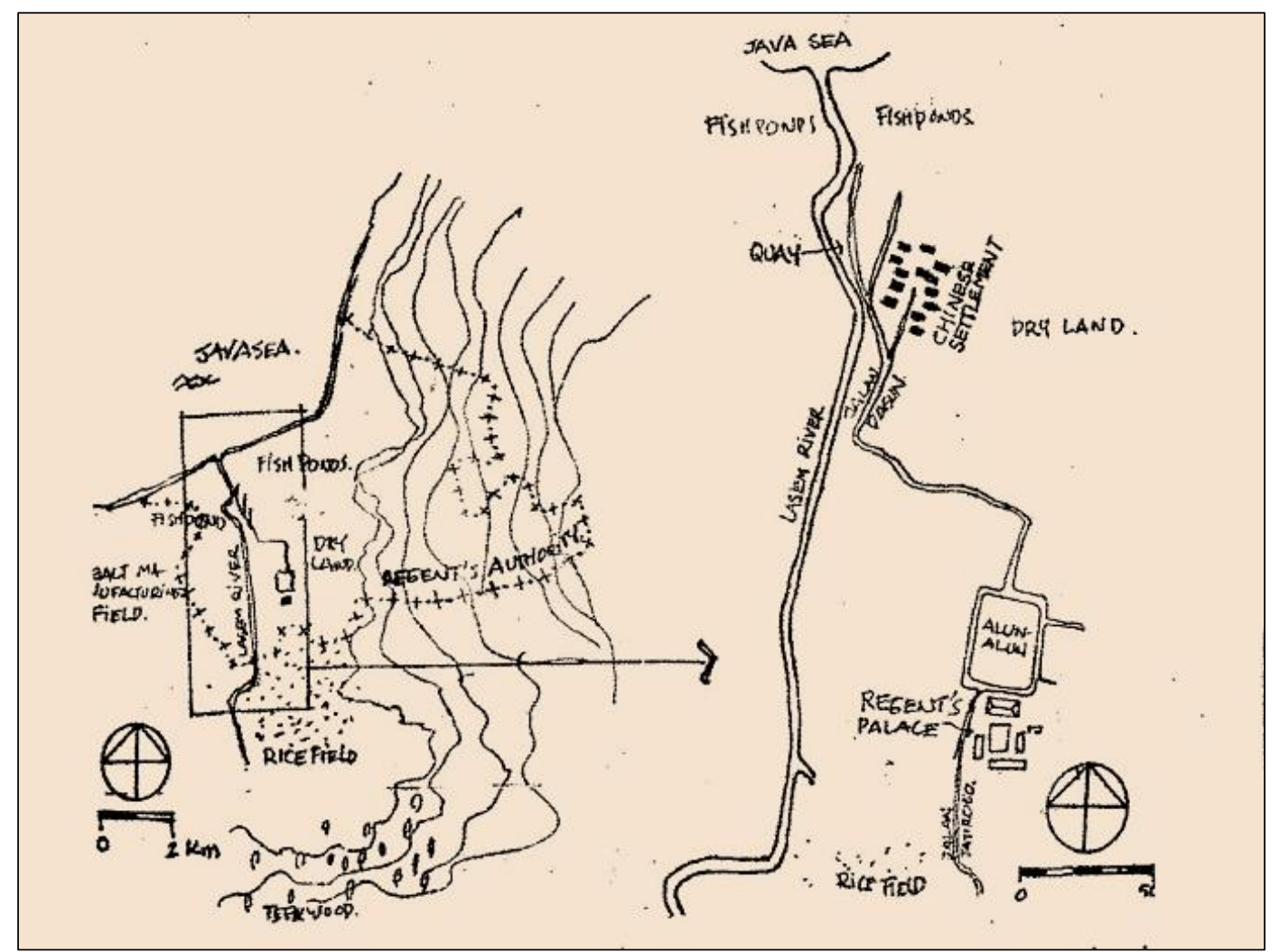

Figure 2. Sketch of Lasem city in the $15^{\text {th }}$ century. There are Square and Ruler's Place components in the South. Chinese settlements are far north of the square approaching the coast

(Source: Pratiwo, 2010 with modifications)

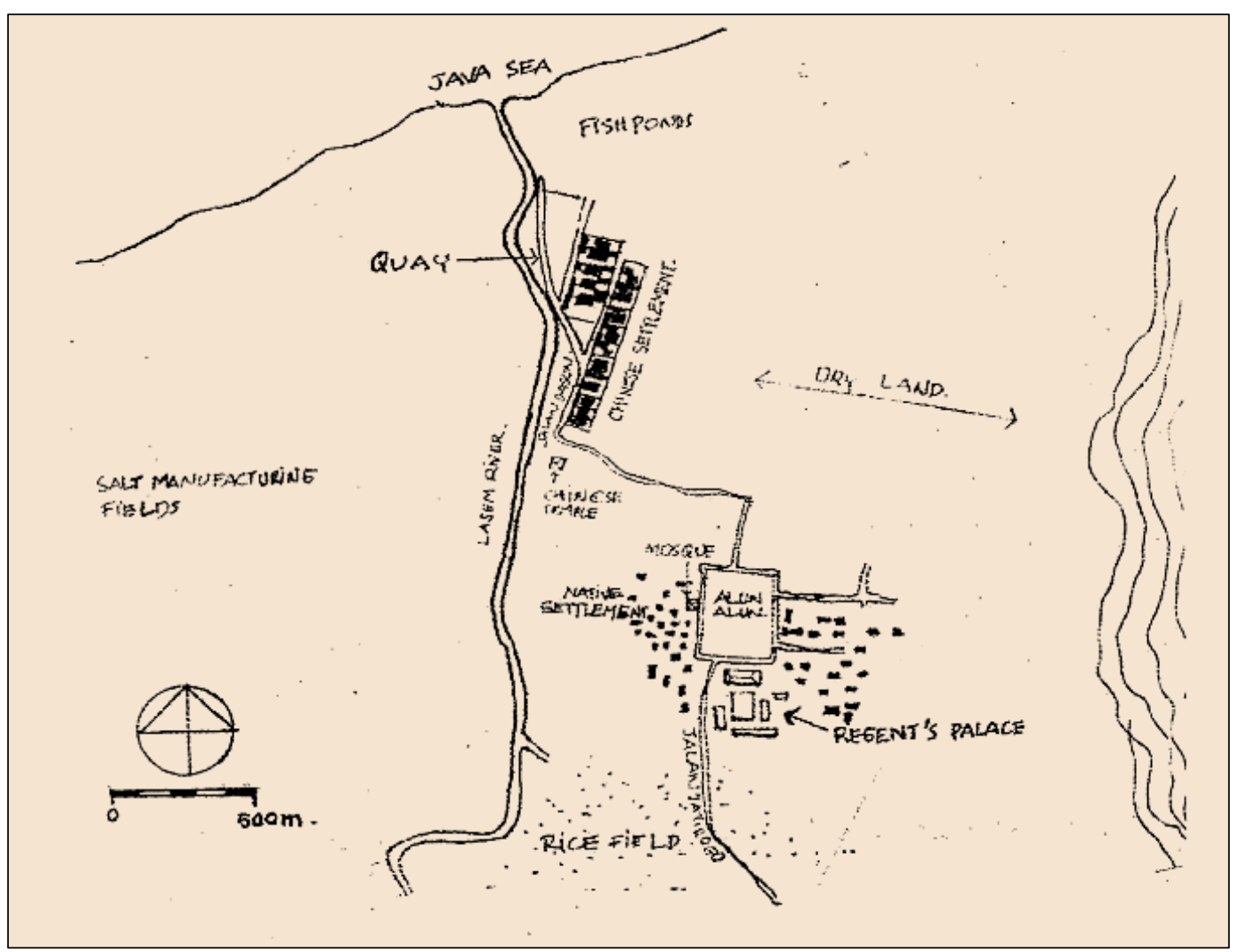

Figure 3. Sketch of Lasem city in the $16^{\text {th }}$ century. There were developments after Islamic Hegemony when the concept of Catur Tunggal grew. In addition to square and ruler's place, the mosque is the component of worship place in the Islamic period, accompanied by the development of surrounding settlements (Source: Pratiwo, 2010 with modifications) 


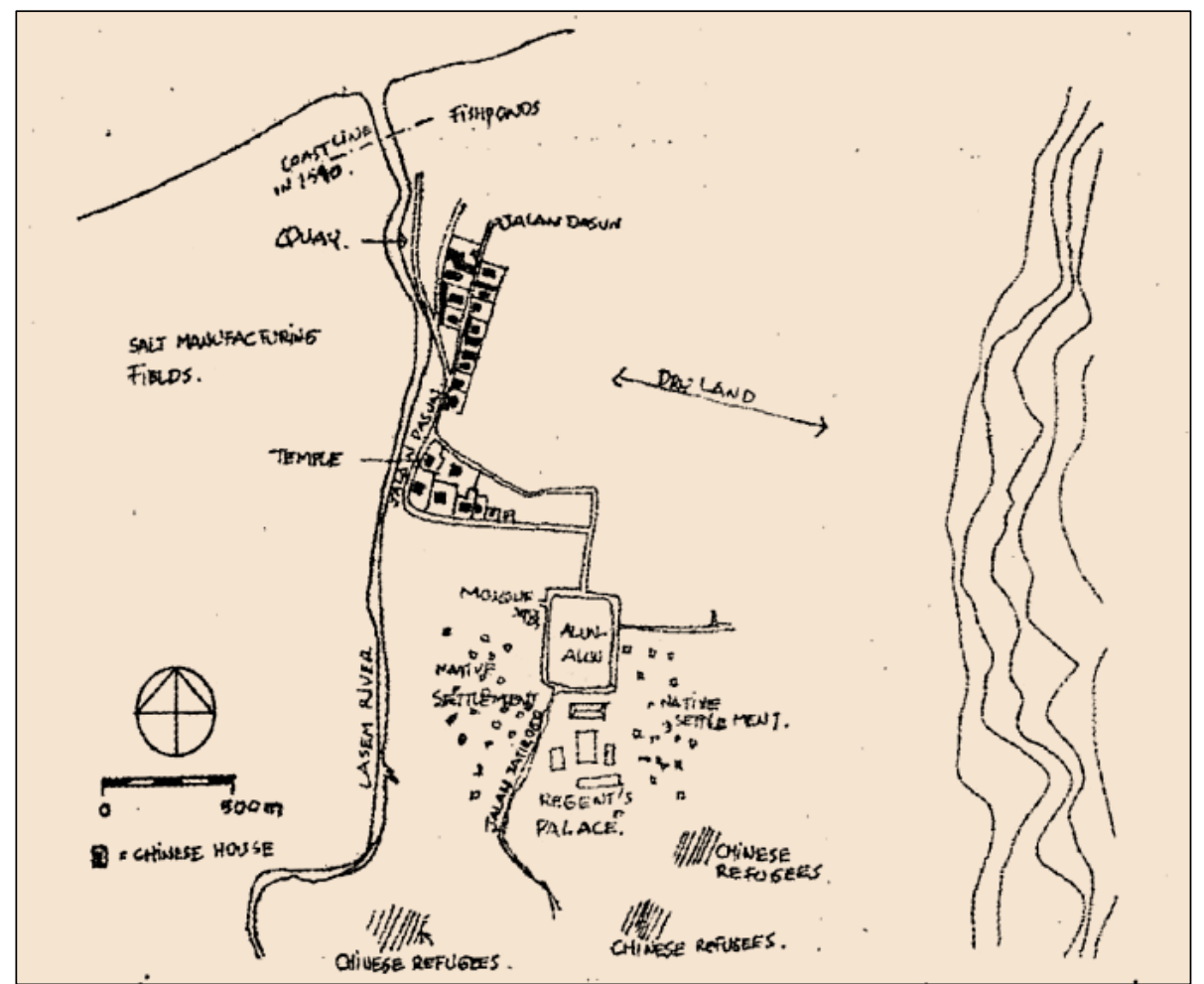

Figure 4. Sketch of Lasem City in the $18^{\text {th }}$ century or around the incident of Chinese rebellion in the 1740s. The significant thing is Chinese settlements are developed to the South (Jalan Dasun)

(Source: Pratiwo, 2010 with modifications)

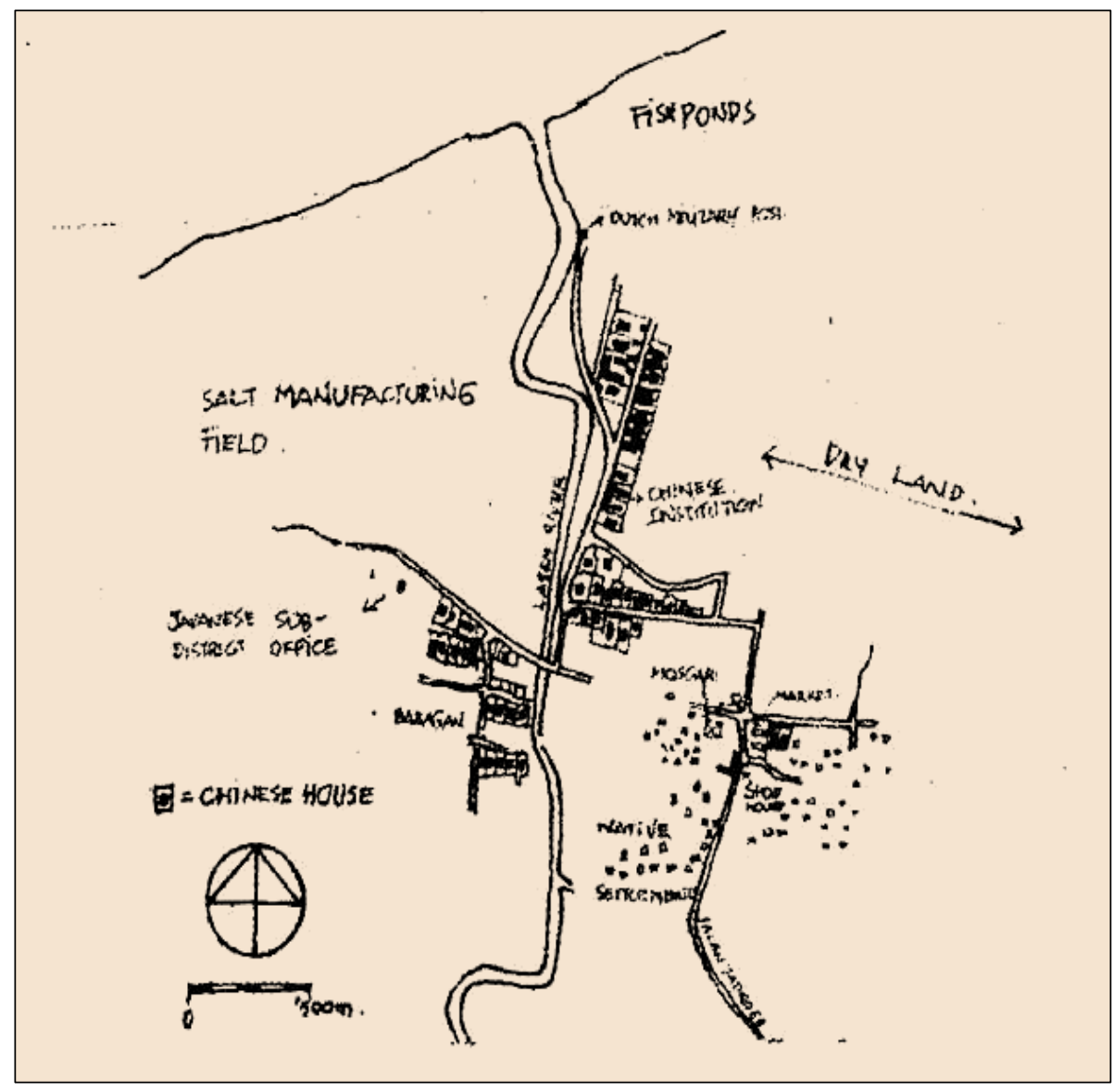

Figure 5. Sketch of Lasem City after the Chinese rebellion. The ruler's place is removed and changed into markets and shops. Chinese settlements are developed further to the south (Jalan Babagan) (Source: Pratiwo, 2010 with modifications) 


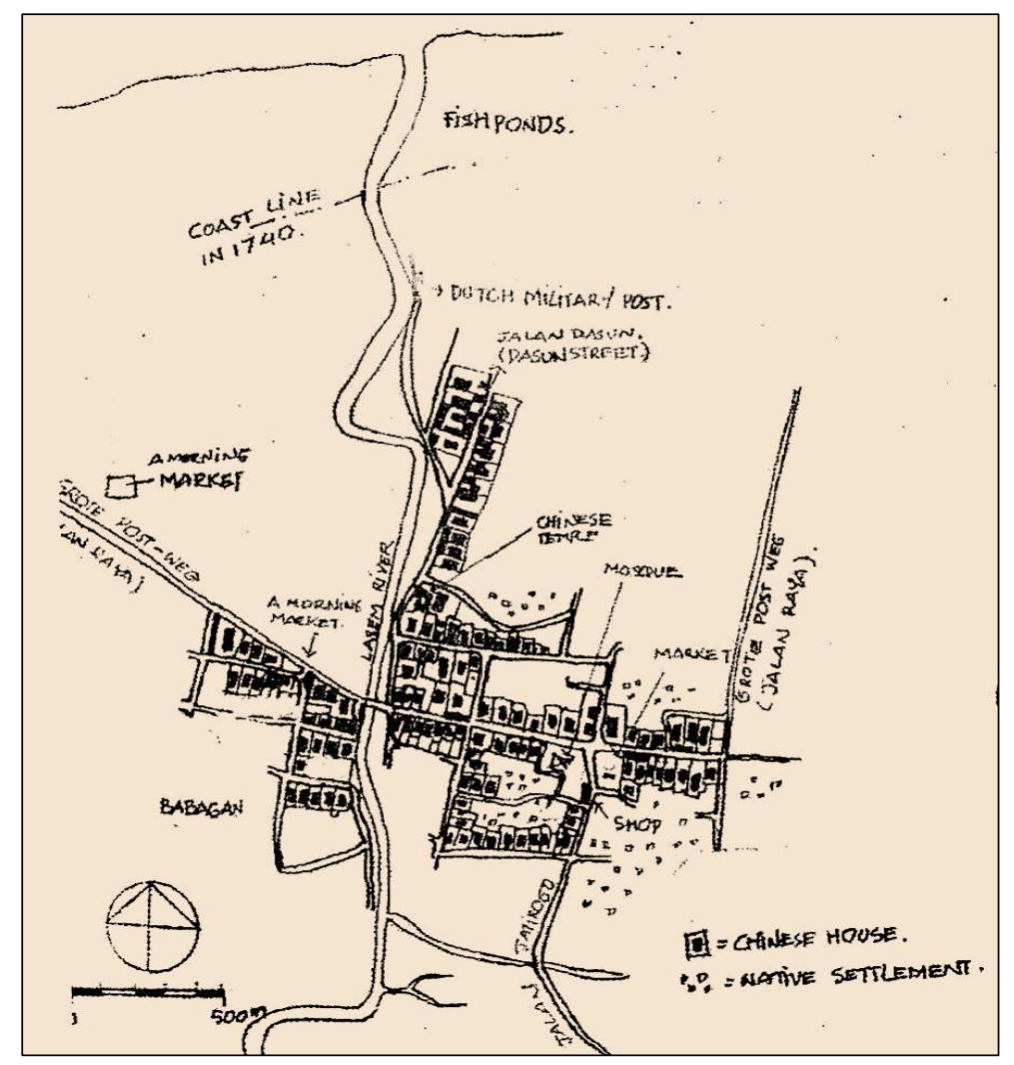

Figure 6. Sketch of Lasem city at the beginning of $19^{\text {th }}$ century. Chinese settlements are developed to the east around the former Square (Jalan Jatiraga) and to the north of the square (Jalan Soditan)

(Source: Pratiwo, 2010 with modifications)

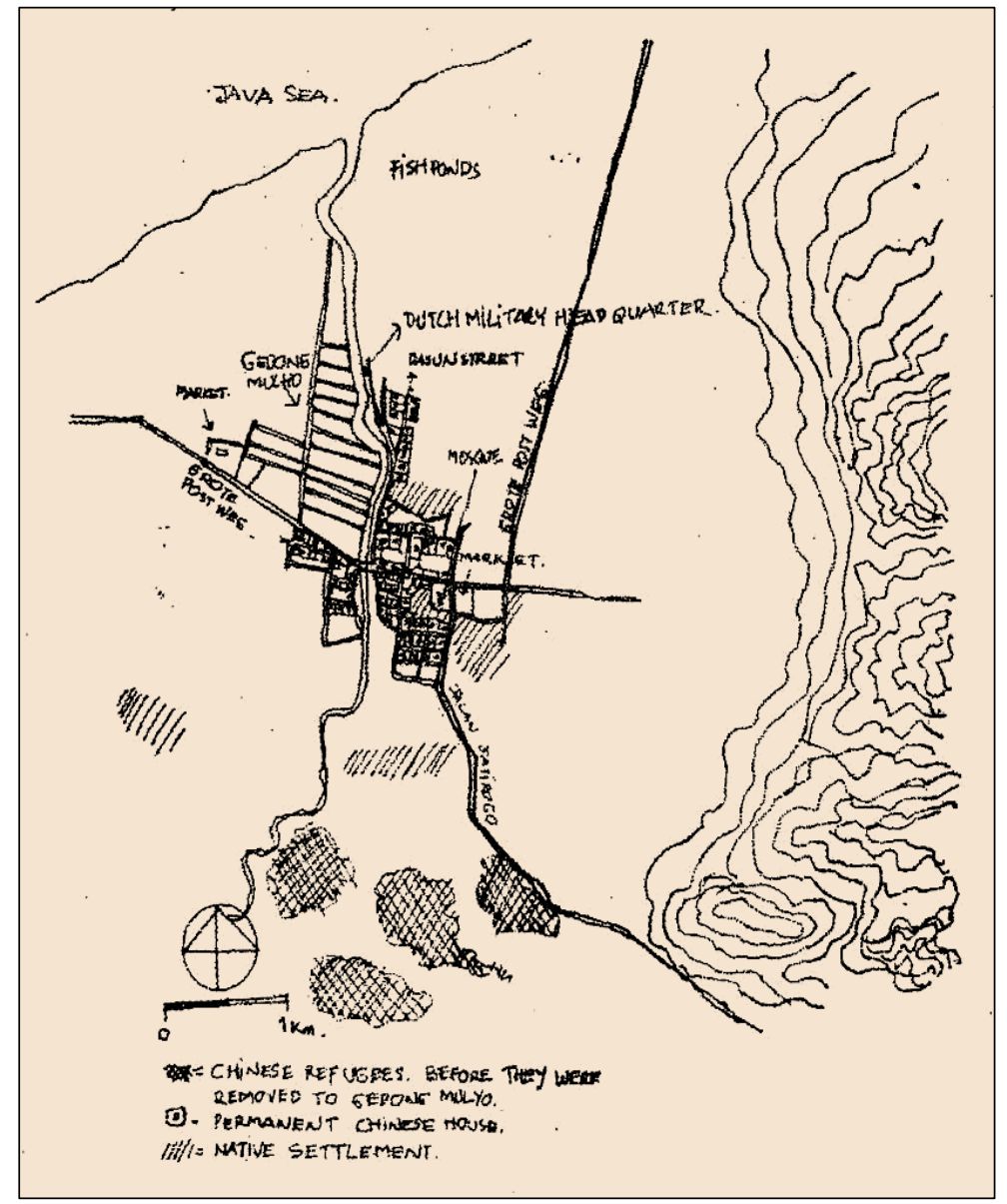

Figure 7. Sketch of Lasem city after the Java War in the 1840s. New Chinese settlements to the west of Jalan Dasun and west of Babagan called Gedong Mulyo

(Source: Pratiwo, 2010 with modifications) 


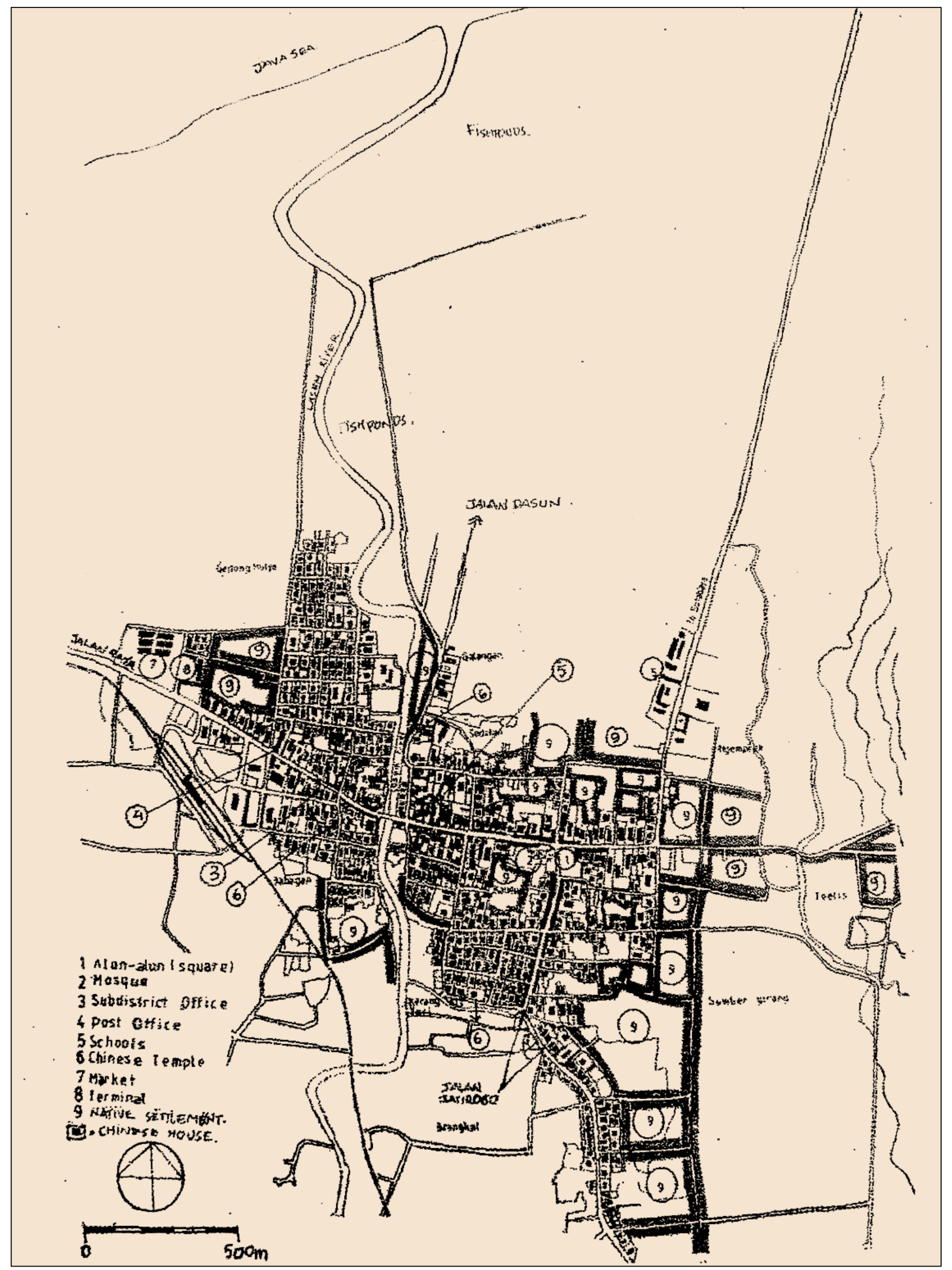

Figure 8. Sketch of Lasem City in the 1990s, there are significant developments in settlements and public facilities (Source: Pratiwo, 2010 with modifications) 


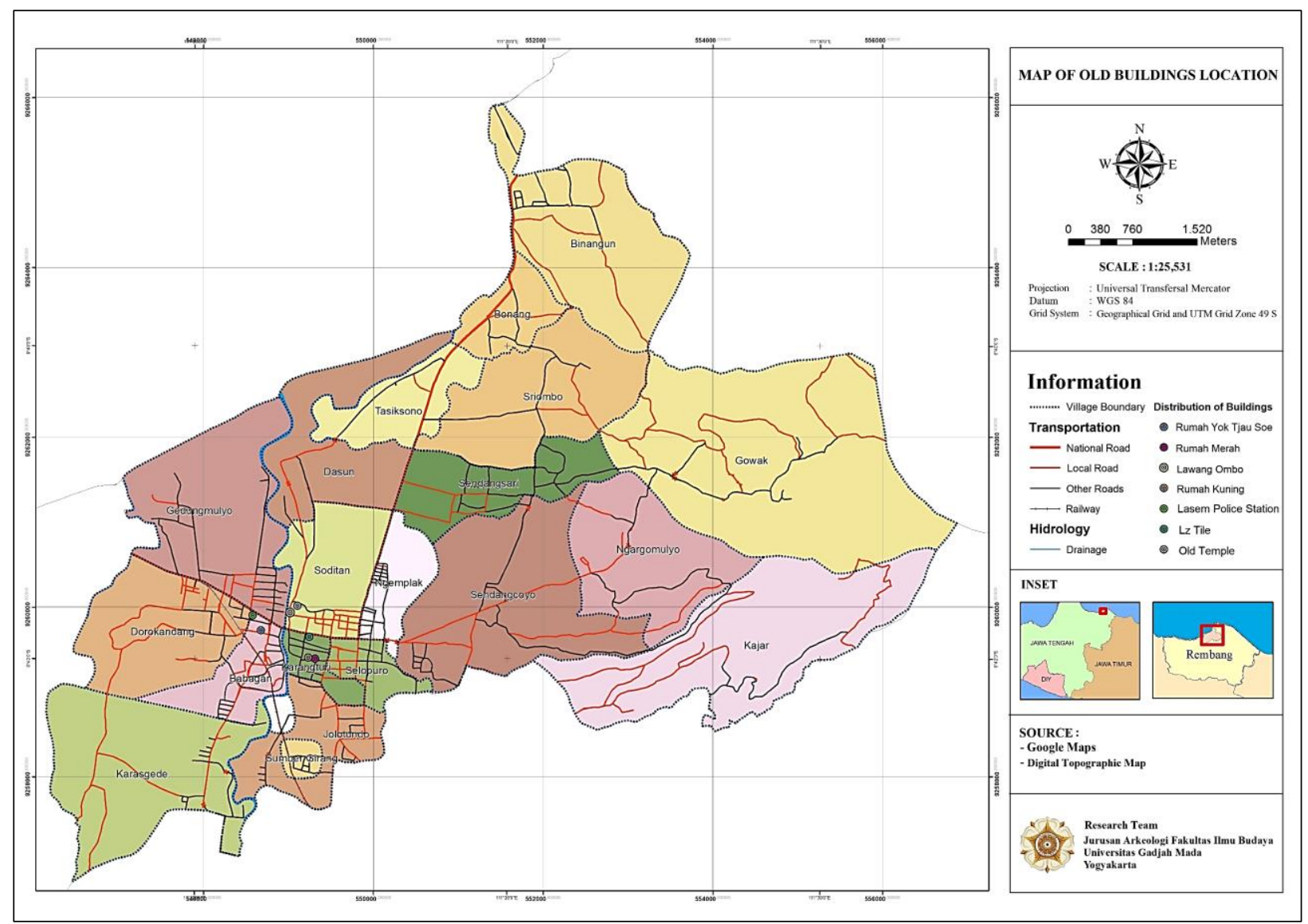

Figure 9. Map of Old Buildings Locations in Lasem Administrative (Source: Putranto \& Pradnyawan, 2018)

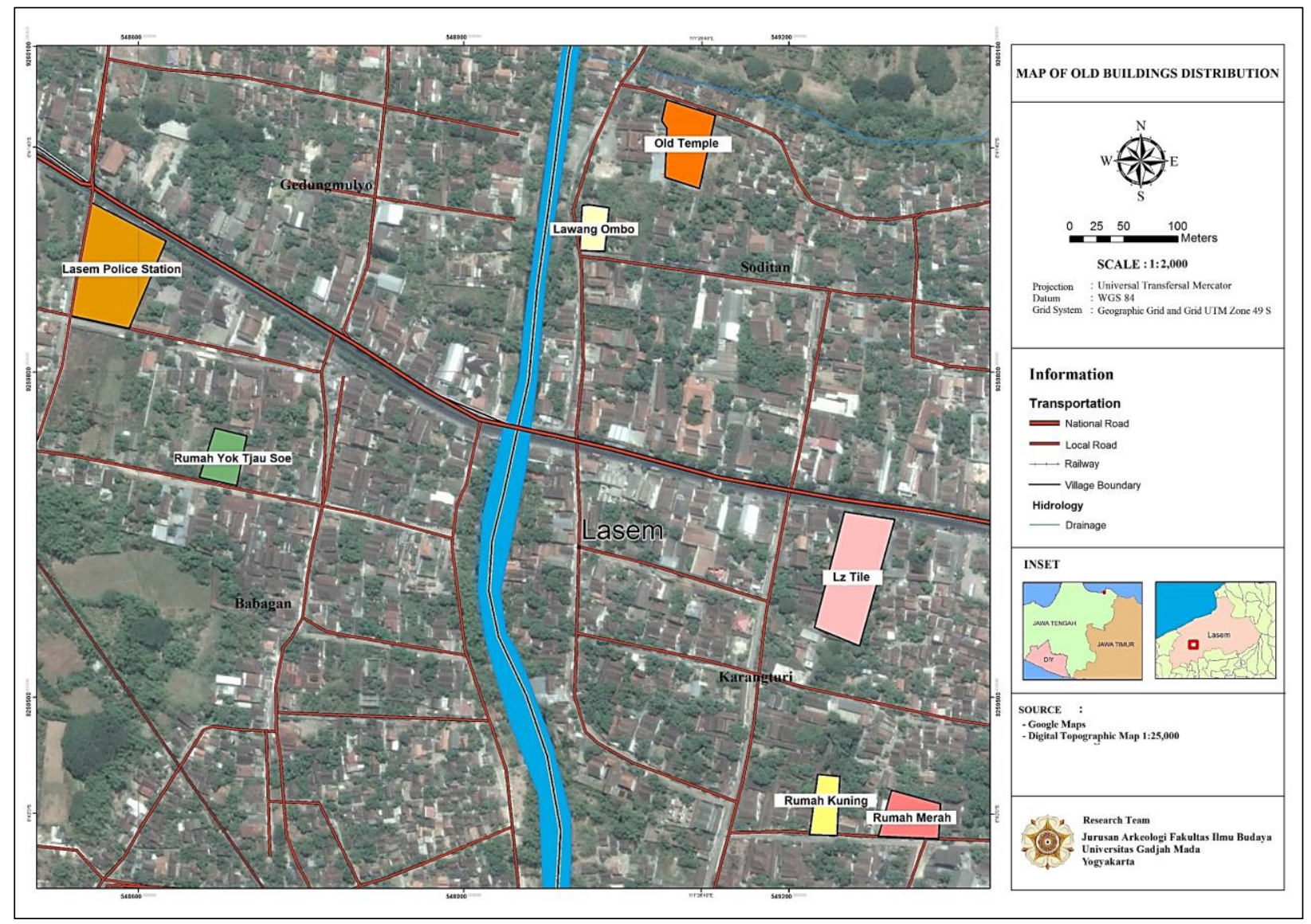

Figure 10. Map of Old Buildings Locations in Lasem (Source: Putranto \& Pradnyawan, 2018) 


\section{Old Buildings in Lasem City}

The earliest settlements of Chinese people were at Jalan Dasun or the northwest area of the square or mosque. Then, the settlements developed into the southern region and then moved to the south of Babagan area now. The settlements further developed into the western area of the mosque and continued to expand to the northern part of the road and to the west of the Daendels Great Post highway (Groote Pos Weg) (Salmon, 1991: 62). There are several types of building in Chinese settlements, namely family house, shophouse, and temples. Each building has certain distinctive characteristics, although in general Chinese houses have a pattern that is based on myth, cosmology, and Chinese philosophy (Nurhajarini, Purwaningsih, \& Fibiona, 2015: 70-71).

This research specifically conducted observations on eight old Chinese buildings in Dasun-Soditan, Babagan, Karangturi, and Gedongmulyo areas. These buildings represent the residential style of the different Chinese community, especially from the characteristics of the architecture. The location of these buildings can seen in the map of Figure 9 and Figure 10.

\section{Lawang Ombo (House of Chinese Captain)}

The Lawang Ombo Chinese House located on Jalan Dasun, an area which is the first Chinese residential area in Lasem. Lawang Ombo is famous as a house with a tragic incident related to its inhabitants. There are also traces of opium tunnel in one side of the house. Lawang Ombo is an old Chinese building that still has the original pattern. Lawan Ombo House is a symbol of resistance to the trade monopoly of Dutch authorities, especially the trade in illegal opium (Subagio, 2013: 121-122).

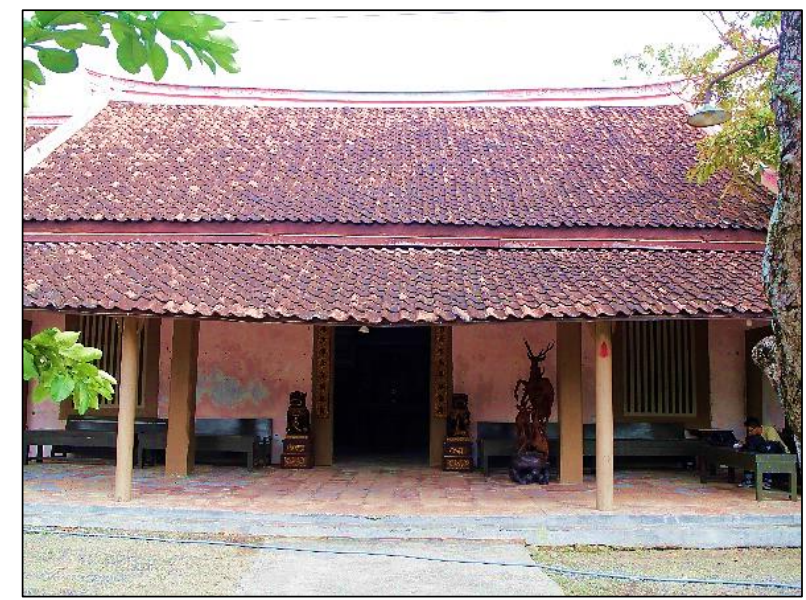

Figure 11. Front View of Lawang Ombo Building (Source: Putranto \& Pradnyawan, 2017)

\section{Rumah Yok Tjau Soe (House of Mr. Junaedi)}

This house is located in the Babagan area. This area is estimated to be a residential area that developed after Jalan Dasun in the north. Like Lawang Ombo, this building shows original features such as the surrounding walls, gates, and massive wooden poles that support the houses that characterize Chinese houses (Wen, 2011: 3; Darmawan \& Hetyorini, 2013: 124).

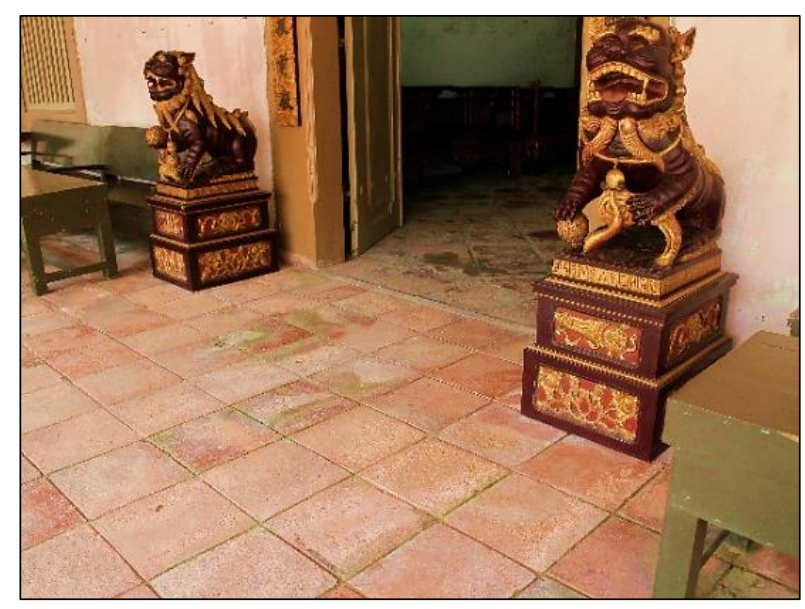

Figure 12. The original Terracotta Brick floor to the Altar Room

(Source: Putranto \& Pradnyawan, 2017)

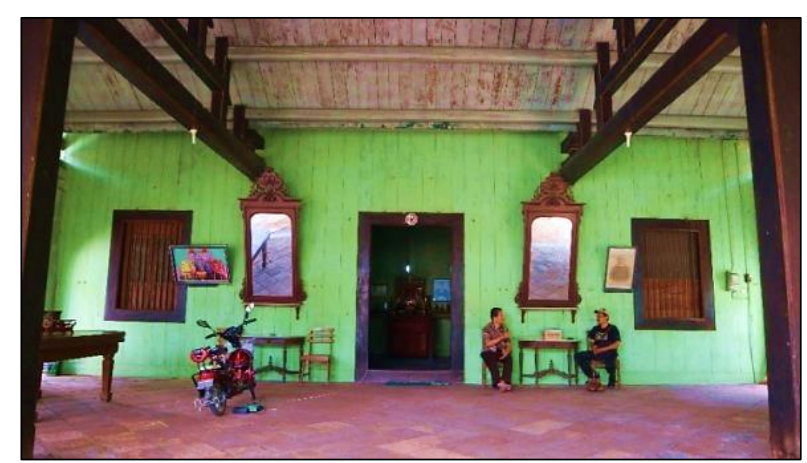

Figure 13. Front Terrace and Entrance to the Altar Room (Source: Putranto \& Pradnyawan, 2017)

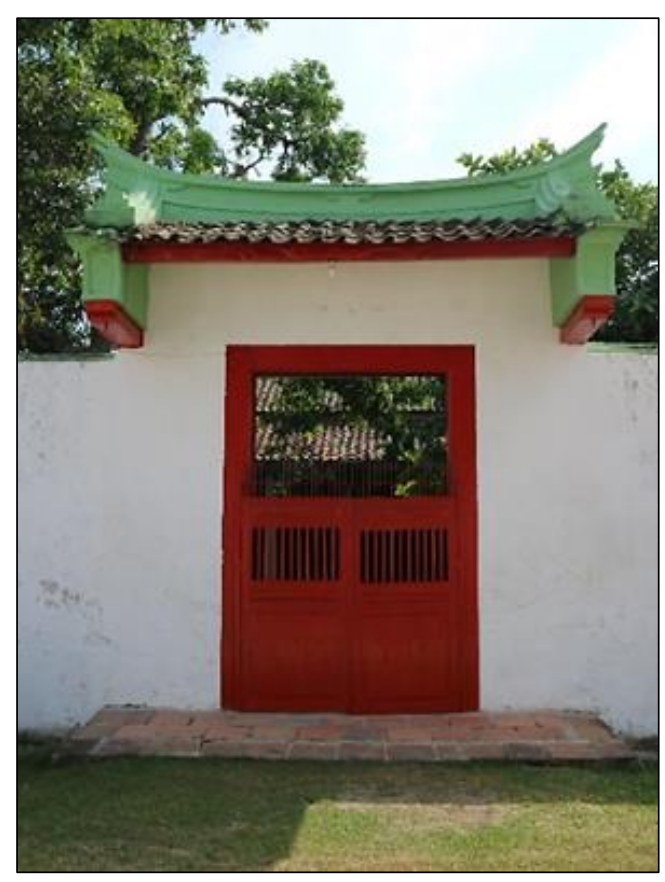

Figure 14. The Main Gate of the House (Source: Putranto \& Pradnyawan, 2017) 


\section{Rumah Opa (Lo Gong Wan)}

The building is a Chinese house that still has its original pattern, although it estimated that it was not established in older times. This house located is in Karangturi region.

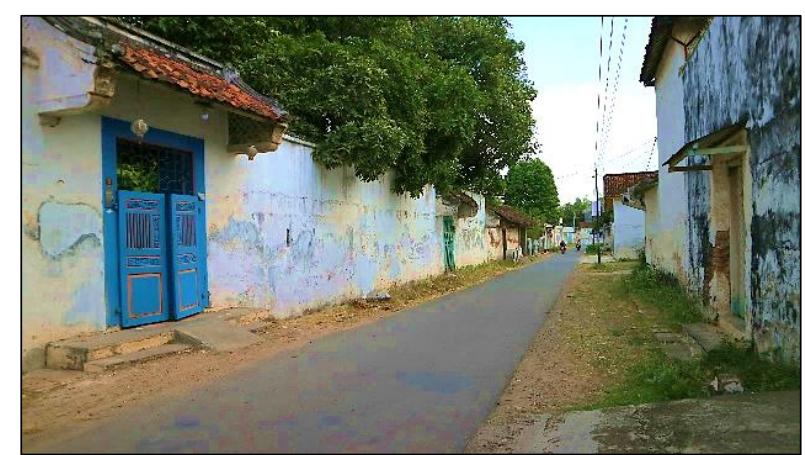

Figure 15. Walls around a Chinese House in Karangturi Region.

(Source: Putranto \& Pradnyawan, 2017)

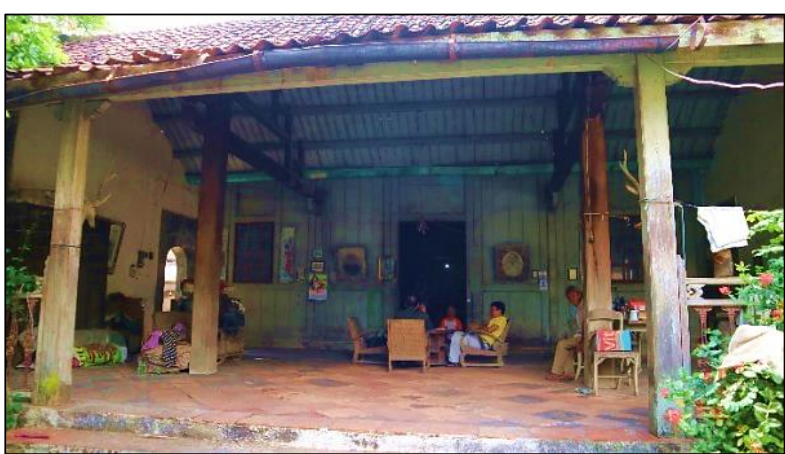

Figure 16. Lo Gong Wan House Terrace Front View. (Source: Putranto \& Pradnyawan, 2017)

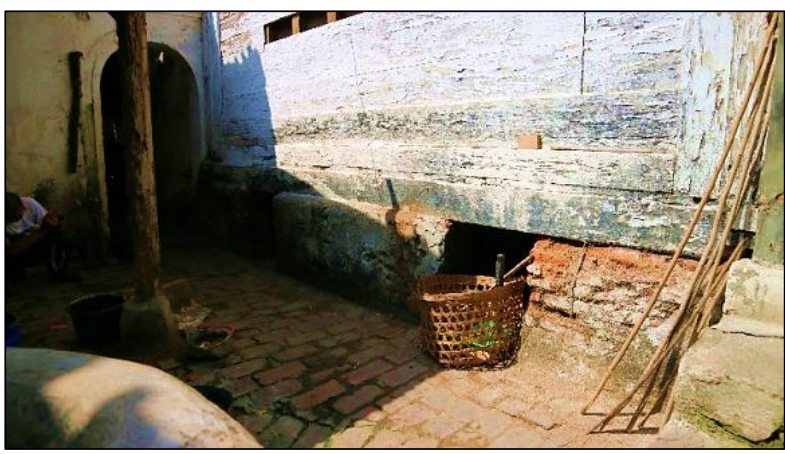

Figure 17. Hollow under the house is one of the characteristics of Chinese house

(Source: Putranto \& Pradnyawan, 2017)

\section{Rumah Merah (House of Mr. Rudy Hartono)}

This house located in Karang Turi. Initially, it has characteristics adapted to the original building pattern of Dutch East Indies architecture. However, the house was restored in such a way that it lost its original characteristics coupled with changes in the current function of the building. The only thing that seems striking is the color of the building which is dominated by red which is a distinctive color that reflects the character of the Chinese color tradition (Suryaningsih \& Purwestri, 2013: 618).

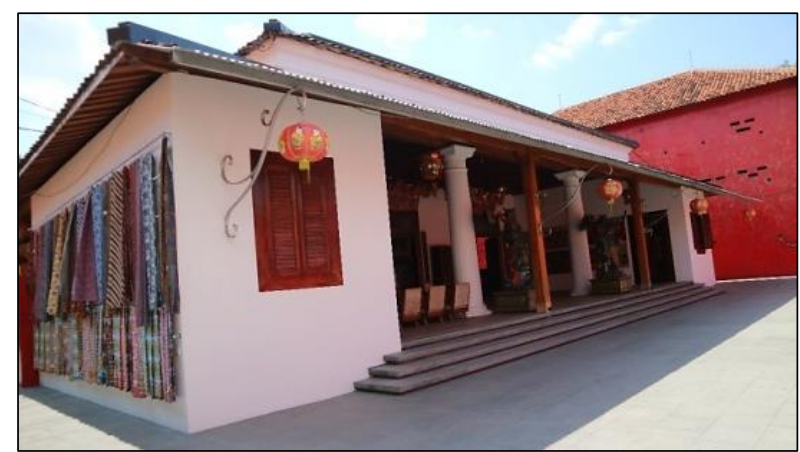

Figure 18. Rumah Merah Building

(Source: Putranto \& Pradnyawan, 2017)

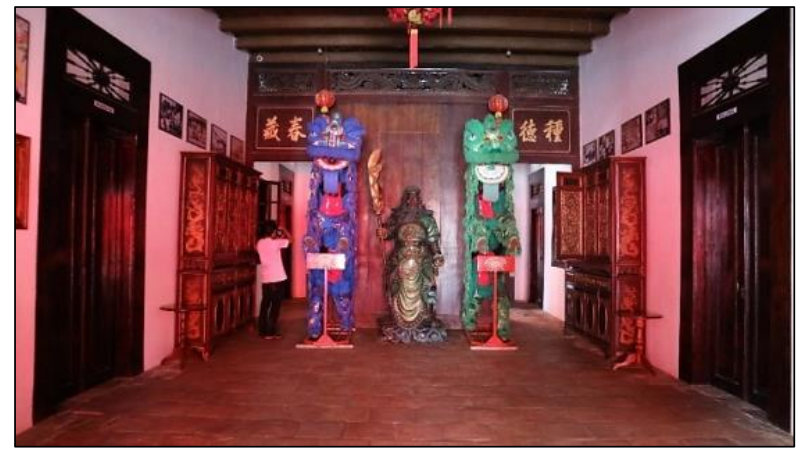

Figure 19. The Altered Altar Room

(Source: Putranto \& Pradnyawan, 2017)

\section{Old Temple Building}

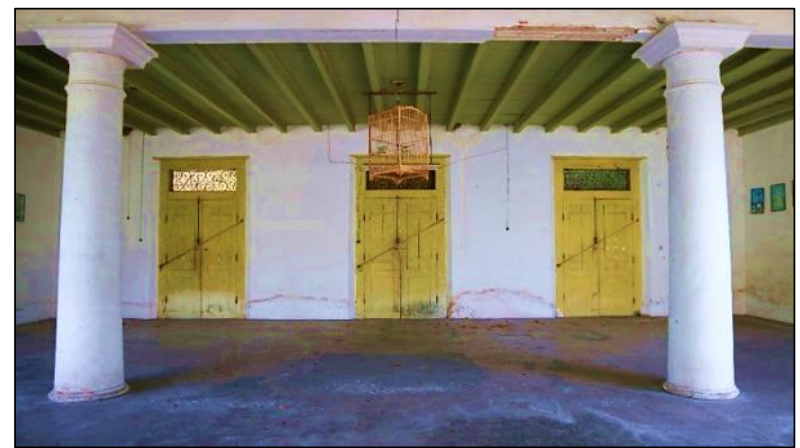

Figure 20. Facade of the Main Building with Massive Concrete Pillars

(Source: Putranto \& Pradnyawan, 2017)

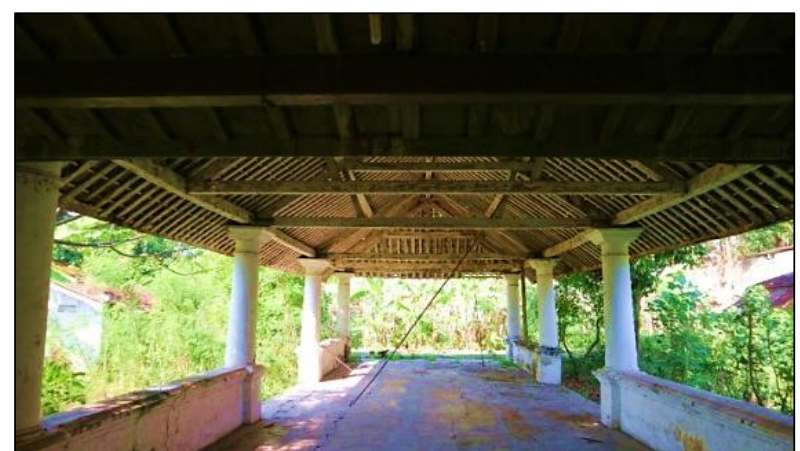

Figure 21. Back Porch of the House with Massive Pillars. (Source: Putranto \& Pradnyawan, 2017)

This building located in the old Lasem region, on Jalan Dasun. It has the characteristics of a Chinese-style house with an adaptation to massive colonial architecture 
(Indische Empire Style). This building is a Chinese house that was built using three types of material, namely wood, stone, and iron. It is a two-story house. Last time, this house was used as a Buddhist temple in Lasem region. It is one of the old buildings that have a large yard compared to other old buildings.

\section{Lasem Police Station Building}

This building located in Gedongmulyo region which is an elite area because it is on the edge of the main road. This house formerly belonged to a wealthy Chinese merchant. The house was built from an original pattern but has adapted to the colonial architectural style (Indische Empire Style). This building is one of the Chinese houses that has large dimensions and fairly complete building features in Lasem. Currently, it is used as Lasem Sector Police Office, and it is a two-story building (with attics).

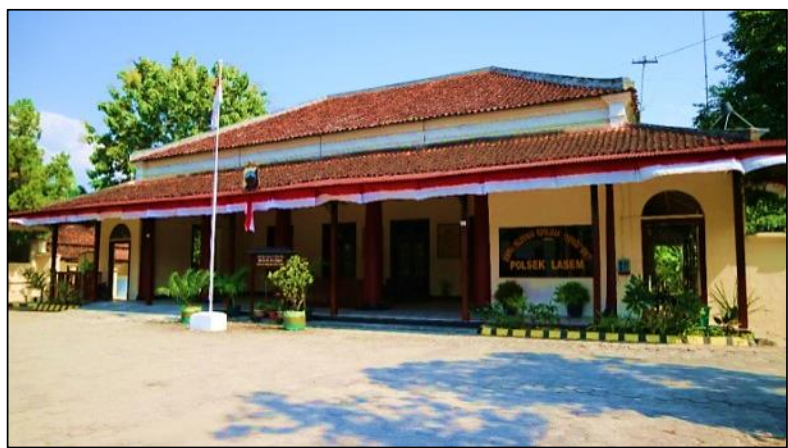

Figure 22. Photo of Lasem Police Sector Building Facade (Source: Putranto \& Pradnyawan, 2017)

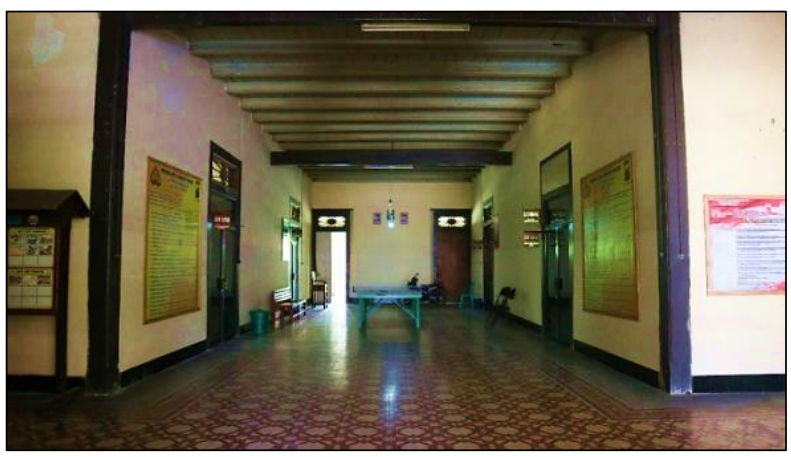

Figure 23. Photo of Living Room (Modified Altar Room) Original tiles with a distinctive decoration can be seen (Source: Putranto \& Pradnyawan, 2017)

\section{Rumah Kuning (House of Mr. Santoso)}

This house has mixed characteristics of the original building pattern with colonial style. This house has the features of merchants' house who modified their house based on colonial architecture. The prominent characteristic of this house is the absence of a gate, as well as the use of tiles and iron materials as building elements. This building looks like Kalang building in Kotagede, Yogyakarta (UNESCO, 2007: 87).

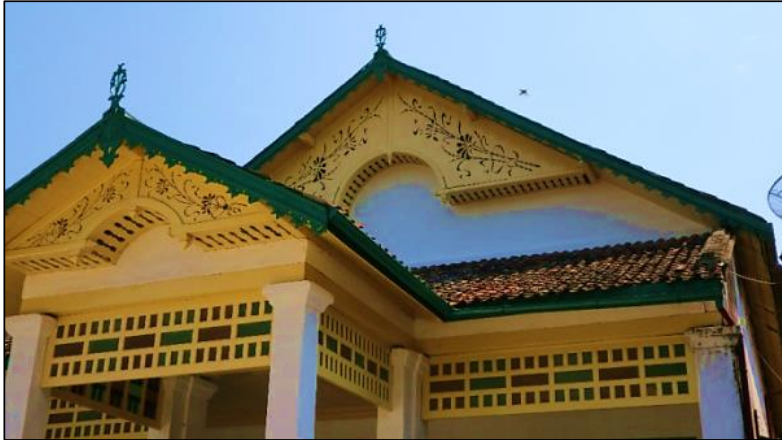

Figure 24. Mr. Santoso's House Facade with Indist Style (Source: Putranto \& Pradnyawan, 2017)

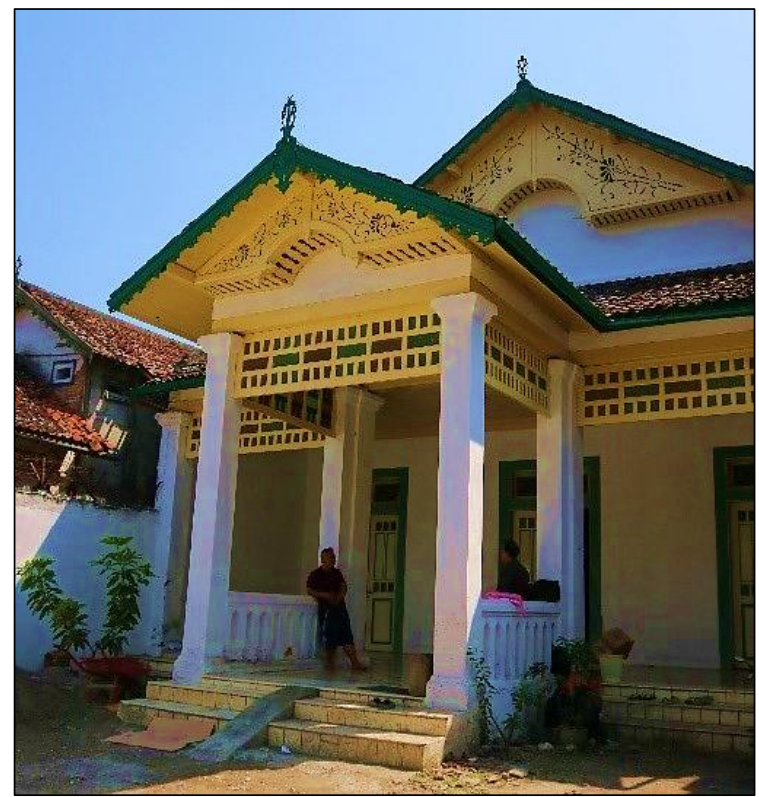

Figure 25. Photo of building facade with rete-rete decoration (Source: Putranto \& Pradnyawan, 2017)

\section{LZ Tile Factory Building}

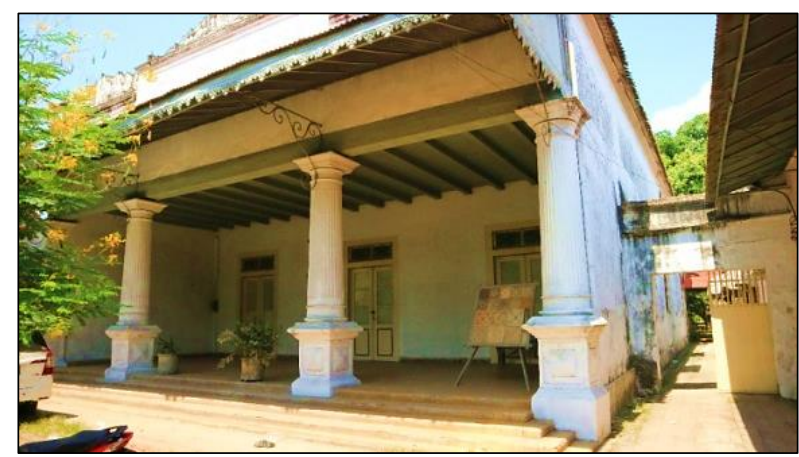

Figure 26. Front View of LZ Tile Factory with style of Indische Empire

(Source. Putranto \& Pradnyawan, 2017)

This building has been entirely adapted to the colonial style or the Dutch East Indies. This building is a combination of house and functioning as a well-known tile factory in Lasem in the past. It has a very large yard like Lasem Police Station building. Chinese elements are quite visible even though they are relatively rare compared to the appearance of colonial style elements (Empire Style). 


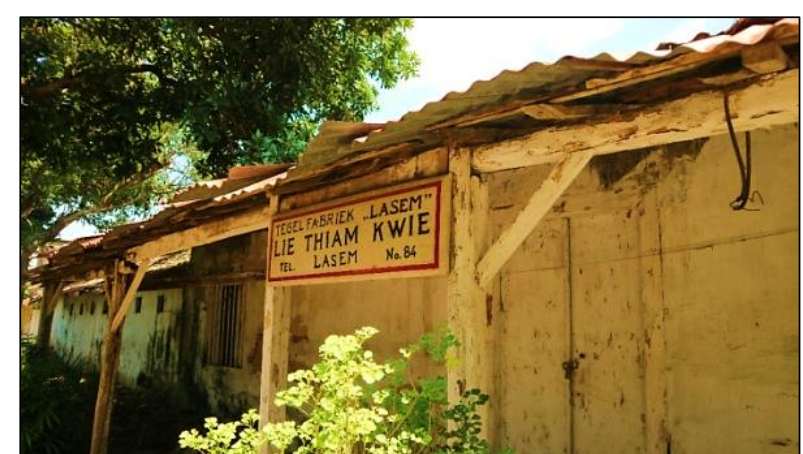

Figure 27. LZ Tile Factory is Located at the Back of the House

(Source: Putranto \& Pradnyawan, 2017)

\section{Building Ranking}

The assessment results of the valuation parameters of the eight buildings in Lasem City, after the calculation of mathematical/algorithmic models specified above, the final total value is obtained as presented in Table 2.

Table 2. Results of Building Final Assessment

\begin{tabular}{llc} 
No & Building Name & $\begin{array}{c}\text { Final } \\
\text { Value }\end{array}$ \\
\hline 1 & Rumah Cina Yok Tjau Soe & 97 \\
\hline 2 & Rumah Merah & 56 \\
\hline 3 & Lawang Ombo House & 109 \\
\hline 4 & LZ Tile Factory & 81 \\
\hline 5 & Rumah Opa (Lo Gong Wan) & 91 \\
\hline 6 & Old Temple & 88 \\
\hline 7 & Rumah Kuning & 79 \\
\hline 8 & Lasem Police Station Building & 83 \\
\hline
\end{tabular}

After obtaining the overall final value of each building in this research, the results were categorized into interval classes that have been previously obtained with the following results:

Table 3. Distribution of Building Interval Classes

\begin{tabular}{cl}
\hline Interval Class & Information \\
\hline $32-56$ & $\begin{array}{l}\text { Not Suitable or Not Recommended for } \\
\text { Designation }\end{array}$ \\
\hline $57-81$ & $\begin{array}{l}\text { Recommended for Designation with } \\
\text { Sufficient Level }\end{array}$ \\
\hline $82-106$ & $\begin{array}{l}\text { Recommended for Designation with } \\
\text { Strong Level }\end{array}$ \\
\hline $107-128$ & $\begin{array}{l}\text { Recommended for Designation with } \\
\text { Urgent Level }\end{array}$ \\
\hline
\end{tabular}

If the division of interval classes is applied to any buildings, it will result in a ranking or priority scale related to the designation recommendations as cultural heritage buildings. Referring to the Law of the Republic of Indonesia No.11. of 2010 on Cultural Heritage in which it is mentioned that buildings that have been designated as cultural heritage would obtain legal protection from acts of destruction, removal, theft, and alteration. As stipulated in the details of the Act (Undang-Undang RI, 2010). Moreover, cultural heritage buildings are also possible to obtain compensation for the designation governed by other applicable regulations in each region according to their rank. In Table 4 is the analysis of the class of each old building in Lasem city based on the assessment results using the method:

Table 4. Building Rank Based on Designation Values and Recommendations

\begin{tabular}{|c|c|c|c|}
\hline $\begin{array}{l}\text { Building } \\
\text { Name }\end{array}$ & $\begin{array}{l}\text { Final } \\
\text { Value }\end{array}$ & $\begin{array}{l}\text { Interval } \\
\text { Class }\end{array}$ & Information \\
\hline $\begin{array}{l}\text { Rumah Cina } \\
\text { Yok Tjau Soe }\end{array}$ & 97 & $82-106$ & $\begin{array}{l}\text { Recommended for } \\
\text { designation with } \\
\text { Strong Level }\end{array}$ \\
\hline Rumah Merah & 56 & $32-56$ & $\begin{array}{l}\text { Not Suitable or Not } \\
\text { recommended for } \\
\text { designation }\end{array}$ \\
\hline Lawang Ombo & 109 & $\begin{array}{l}107- \\
128\end{array}$ & $\begin{array}{l}\text { Recommended for } \\
\text { designation with } \\
\text { Urgent Level }\end{array}$ \\
\hline LZ Tile Factory & 81 & $57-81$ & $\begin{array}{l}\text { Recommended for } \\
\text { designation with } \\
\text { Sufficient Level }\end{array}$ \\
\hline $\begin{array}{l}\text { Rumah Opa } \\
\text { (Lo Gong } \\
\text { Wan) }\end{array}$ & 91 & $82-106$ & $\begin{array}{l}\text { Recommended for } \\
\text { designation with } \\
\text { Strong Level }\end{array}$ \\
\hline Old Temple & 88 & $82-106$ & $\begin{array}{l}\text { Recommended for } \\
\text { designation with } \\
\text { Strong Level }\end{array}$ \\
\hline $\begin{array}{l}\text { Rumah } \\
\text { Kuning }\end{array}$ & 79 & $57-81$ & $\begin{array}{l}\text { Recommended for } \\
\text { designation with } \\
\text { Sufficient Level }\end{array}$ \\
\hline $\begin{array}{l}\text { Lasem Police } \\
\text { Station } \\
\text { Building }\end{array}$ & 78 & $57-81$ & $\begin{array}{l}\text { Recommended for } \\
\text { designation with } \\
\text { Sufficient Level }\end{array}$ \\
\hline
\end{tabular}

The results of the above assessment illustrate that there is one building that is recommended for designation as a Cultural Heritage with urgent level from the eight old buildings in Lasem City, namely the House of Chinese Captain or Lawang Ombo. While in the next rank, three buildings are recommended for designation with strong level (Rumah Yok Tjau Soe, Rumah Opa, and Old Temple). Three buildings are recommended for designation with sufficient level, namely Rumah Kuning, LZ Tile Factory, and Lasem Police Station as well as one building which is not recommended for designation, namely Rumah Merah.

The house of Chinese Captain or better known as Lawang Ombo and the opium house received an urgent predicate for designation by obtaining the highest score because of the historical parameters obtained high scores. This is because the house has important historical stories related to homeowners as figures in the history of resistance to colonial rule (VOC) in the past. Moreover, in the history of the opium trade, this house played a significant role as the place where opium smuggling took place through its underground tunnel. As for Rumah Yok Tjau Soe, Rumah Opa has firm Chinese characteristics which are both included in the oldest architectures of family house type building in Lasem. In fact, there are allegations that the architectural style affects traditional Javanese architecture in the future. The two buildings 
together with the Old Temple building can be recommended at a strong level for designation as Cultural Heritage Buildings in Lasem City.

In the next ranking level, which is the sufficient level to designate as a Cultural Heritage Building, are Rumah Kuning, LZ Tile Factory, and Lasem Police Station Office. The three buildings architecturally represent different styles, they use empire style like buildings in Europe, but they adapt to tropical environmental conditions in Indonesia. This style represents a younger architectural style and represents a different social class compared to the type of Chinese architectural style of a family house.

The lowest level is Rumah Merah, which is at the level that is not recommended for determination. This is because the condition of the building has undergone significant changes from its authentic condition. At this time there were enough of the original architectural traits that were lost which at the beginning of the construction of the building should show Chinese architecture with the type of family house.

\section{Conclusion}

The results of this research have succeeded in applying the building assessment model with tiered quantitative analysis with weighting factors. This method cannot be applied without modifying/adjusting parameters according to the character of old buildings in Indonesia. Providing weighting factors is a more real step in order to be able to get closer to the reality of the research object in the field, namely old buildings as is usually performed in land assessment evaluation activities in geography, geology, forestry, and agricultural science. This makes the assessment results more appropriate to the conditions and objectives to be obtained. The weighting factors can change its value according to the purpose of the assessment itself. The assessment of recommendations for designating and evaluating for utilization will differ in the amount of the weighting factor value, and even the parameters used will be added or reduced.

The research results indicate the final value of old buildings in Lasem City which can be used as input or recommendations for designation with different priority levels. The House of Captain or Opium House is an old building which according to the assessment results is a building that ranks first in the assessment, which means entering an urgent level if it will be designated as a Cultural Heritage. Another result is a building of a family house or Rumah Cina Yok Tjau Soe, Lo Gong Wan, and Old Temple are at a strong level to be designated as a cultural heritage. Furthermore, being at a sufficient level is the LZ Tile Factory building, Old Temple, and Lasem Police Station Office. The lowest level is the building of family house which is now known as Rumah Merah. This building obtains a value of not suitable or not recommended for designation as a cultural heritage building regarding the final results of the assessment. This is because the current conditions that can be observed indicate that many changes have been made to the physical building in case of adaptive reuse the function of the building at this time as a tourist attraction. Hopefully, in the future, the assessment model in this way will be able to continue to be tested against other old buildings in Indonesia by taking randomly constructed building samples or not at all. Besides, particular research needs to be conducted to obtain the selected weighting parameters and factors in order to further refine this assessment model in the future.

\section{ACKNOWLEDGEMENT}

We would like to express our gratitude to Lasem Research Team 2018, and all parties involved in contributing the information, data, and thoughts during the preparation of this publication, as well as to all members of the Editorial Board and two Anonymous Reviewers in Kapata Arkeologi who assisted us maintaining the quality of this scientific article.

\section{$* * * * *$}

\section{REFERENCES}

Armani, S., \& Arbi, E. (2014). A Comparative Study on Chinese Architecture in Peninsular Malaysia and Mainland China. Journal Of Design And Built Environment, 14(2), $1-12$.

Atabik, A. (2016). Harmonisasi Kerukunan Antar Etnis dan Penganut Agama di Lasem. Fikrah, 4(1), 36-49.

de Graaf, H. J., \& Pigeaud, T. H. (2003). Kerajaan Islam Pertama di Jawa: Tinjauan Sejarah Politik abad XV dan XVI. Jakarta: PT Pustaka Utama Grafiti.

Djafar, H. (2009). Masa Akhir Majapahit: Girindrawardhana dan Permasalahannya. Jakarta: Komunitas Bambu.

Darmawan, D., \& Hetyorini. (2013). Yin Yang, Chi dan Wu Xing pada Arsitektur Kelenteng: Studi Kasus Kelenteng Sebelum Abad 19 di Lasem, Rembang, dan Semarang. Serat Acitya, 2(3), 115-128.

Esri Press Team. (2018). How To Perform Spatial Analysis. Retrieved February 28, 2018, from https://www.esri.com/

Grementieri, F. (2003). The Preservation of Nineteenth and Twentieth Century Heritage. In R. van Oers, \& S. Haraguchi (Eds.), World Heritage Papers 5: Identification and Documentation of Modern Heritage (pp. 81-88). Paris: UNESCO World Heritage Centre.

Gunawan, Y., Rachim, Y. F., \& Fabiano, C. (2008). Leksikon Arsitektur Lasem: Studi Perbandingan Rumah Jawa, Cina dan Kolonial. In P. Salura, \& Y. Gunawan (Eds.), Pertemuan Arsitektur Pantai Utara Jawa: Cirebon, Tegal, Pekalongan, Semarang, Lasem, Tuban (pp. 57-73). Bandung: Cipta Sastra Salura. 
Handinoto. (2015). Lasem: Kota Tua Bernuansa Cina di Jawa Tengah. Yogyakarta: Penerbit Ombak.

Hardjowigeno, S., \& Widiatmaka. (2007). Evaluasi Kesesuaian Lahan dan Perencanaan Tataguna Lahan. Yogyakarta: Gadjah Mada University Press.

Kalman, H. (1980). The Evaluation of Historic Buildings. Ottawa: Environment Canada, Parks Service.

Nurhajarini, D. R., Purwaningsih, E., \& Fibiona, I. (2015). Akulturasi Lintas Zaman di Lasem: Perspektif Sejarah dan Budaya (Kurun Niaga-Sekarang). Yogyakarta: Balai Pelestarian Nilai Budaya (BPNB) Yogyakarta.

Pratiwo, \& Nazir, S. M. (2010). Arsitektur Tradisional Tionghoa dan Perkembangan Kota. Yogyakarta: Penerbit Ombak.

Putranto, A., \& Pradnyawan, D. (2017). Laporan Penelitian: Penilaian Bangunan Tua di Kota Lasem Berdasarkan Metode Analisis Kuantitatif Berjenjang dengan Faktor Pembobot. Yogyakarta: FIB Universitas Gadjah Mada.

Putranto, A., Sutikno, S., \& Suharyadi, S. (2015). Integrasi Foto Udara dan Sistem Informasi Geografis untuk Evaluasi Penentuan Letak Bangunan Candi di Wilayah Prambanan, Klaten, Jawa Tengah dan Daerah Istimewa Yogyakarta. Majalah Geografi Indonesia, 29(1), 1-6.

Roosmalen, P. V. (2003). Changing Views on Colonial Heritage. In R. van Oers, \& S. Haraguchi (Eds.), World Heritage Papers 5: Identification and Documentation of Modern Heritage (pp. 121-129). Paris: UNESCO World Heritage Centre.

Salmon, C. (1991). The Han Family of East Java. Entrepreneurship and Politics (18th-19th Centuries). Archipel, 41(1), 53-87.

Septirina, S. N., Takeo, O., \& Satoru, K. (2016). Conservation of Historical Architecture in Malioboro Street, Yogyakarta City, Indonesia. Procedia - Social and Behavioral Sciences, 225, 259-269.

Suharyadi, \& Aktiva, P. (2005). Pemodelan Spasial Tingkat Kerawanan Kecelakaan Lalu Lintas di Surabaya Pusat dengan Memanfaatkan Foto Udara. In Pertemuan Tahunan MAPIN XIV. Surabaya: Institut Teknologi Sepuluh November.

Subagio, D. D. (2013). Pemanfaatan Benda Cagar Budaya Rumah Candu di Lasem. In Prosiding The $5^{\text {th }}$ International Conference on Indonesian Studies: Ethnicity and Globalization (pp. 121-132). Depok: FIB Universitas Indonesia.

Suryaningsih, F., \& Purwestri, N. (2013). Documenting Living Monuments in Indonesia: Methodology for Sustainable Utility. ISPRS-International Archives of the Photogrammetry, Remote Sensing and Spatial Information Sciences, (2), 617-622.

Undang-Undang RI. UU tentang Cagar Budaya, Pub. L. No. 11 (2010). Indonesia.

UNESCO. (2007). Homeowner's Conservation Manual: Kotagede heritage district, Yogyakarta, Indonesia. Jakarta: UNESCO House.

URHC Team. (2013). Guidelines to the Survey of Buildings and Open Spaces. Cairo: UNESCO and Historic Cairo World Heritage Property.

Wen, R. (2010). Architecture and Tradition. Master Thesis Unitec Institute of Technology. 